\title{
A New Cell-to-Cell Transport Model for Potexviruses
}

\author{
Jeanmarie Verchot-Lubicz \\ Oklahoma State University, Department of Entomology and Plant Pathology, Noble Research Center Rm 127, Stillwater, OK \\ 74078, U.S.A.
}

Submitted 7 July 2004. Accepted 22 November 2004.

In the last five years, we have gained significant insight into the role of the Potexvirus proteins in virus movement and RNA silencing. Potexviruses require three movement proteins, named triple gene block (TGB)p1, TGBp2, and TGBp3, and the viral coat protein (CP) to facilitate viral cell-to-cell and vascular transport. TGBp1 is a multifunctional protein that has RNA helicase activity, promotes translation of viral RNAs, increases plasmodesmal size exclusion limits, and suppresses RNA silencing. TGBp2 and TGBp3 are membrane-binding proteins. $\mathrm{CP}$ is required for genome encapsidation and forms ribonucleoprotein complexes along with TGBp1 and viral RNA. This review considers the functions of the TGB proteins, how they interact with each other and $C P$, and how silencing suppression might be linked to viral transport. A new model of the mechanism for Potexvirus transport is proposed.

Additional keywords: plasmodesmata transport, triple gene block.

Plant viruses encode movement proteins (MPs) that promote virus cell-to-cell and vascular transport. In several studies, viral genes encoding MPs have been interchanged between viral genomes to yield chimeric viruses that are infectious (Agranovsky et al. 1998; Giesman-Cookmeyer et al. 1995; Solovyev et al. 1996, 1999; Tamai et al. 2003). Other tests conducted by coinfecting plant viruses have shown that the MP of one virus alleviates cell type or host restrictions for another virus (Mayo et al. 2000; Mise and Ahlquist 1995; Mise et al. 1993; Morozov et al. 1997; Palukaitis and Garcia-Arenal 2003; Ryabov et al. 1999; Syller 2002). Because of the interchangeability of viral MPs, researchers have proposed general models to describe the transport mechanisms for a wide range of plant viruses.

In one of the first general models that was proposed to explain virus cell-to-cell movement, viral MPs bind to the viral genomic nucleic acid (Citovsky et al. 1990, 1992; Hehnle et al. 2004; Ivanov et al. 1994; Kalinina et al. 2001; Kiselyova et al. 2001; Osman et al. 1993; Rojas et al. 1998) and carries it across plasmodesmata into adjacent cells (Alzhanova et al. 2001; Fujita et al. 1998; Giesman-Cookmeyer and Lommel 1993; Gilbertson et al. 2003; Noueiry et al. 1994; Soellick et al. 2000). This model was based on early microinjection and biolistic bombardment studies, indicating that plant viral MPs often increase plasmodesmal permeability to promote virus cell-to-cell movement. The MPs of Tobacco mosaic virus (TMV), Red clover necrotic mosaic virus (RCNMV), Bean dwarf mosaic virus (BDMV), Tobacco rattle virus (TRV), and Cucumber mosaic virus (CMV) were shown in microinjection

Corresponding author: J. Verchot-Lubicz; E-mail: verchot@okstate.edu studies to increase plasmodesmal size exclusion limit (SEL) in tobacco leaves to allow movement of large fluorescent dyes $(\geq 10 \mathrm{kDa}$ ) between neighboring cells (Derrick et al. 1992; Ding et al. 1995; Fujiwara et al. 1993; Noueiry et al. 1994; Wolf et al. 1991). Also using microinjection, viral MPs facilitated the movement of nucleic acids from cell to cell (Ding et al. 1995). In other experiments, plasmids expressing green fluorescent protein (GFP) fused to the MP genes of TMV or CMV were biolistically delivered to single leaf epidermal cells and protein movement was directly observed (Crawford and Zambryski 2001; Itaya et al. 1998).

We now know from studies of GFP and plant transcription factors that the aperture of plasmodesmata can fluctuate during leaf development and according to changes in the environment (Lucas and Lee 2004; Zambryski 2004). Although prior microinjection studies have set the plasmodesmal SEL at or below 1 $\mathrm{kDa}$, we now know that larger proteins can diffuse through plasmodesmata. Diffusion of proteins across plasmodesmata might occur when plasmodesmata are dilated, allowing molecules to freely move from cell to cell (Zambryski 2004). This is in contrast to microinjection and biolistic bombardment studies showing viruses use a targeted mechanism to move cell to cell. In a recent review of plasmodesmata function, it was proposed that movement of viral ribonucleoprotein complexes follows a cellular pathway for movement of non-cell-autonomous proteins (NCAP) (Lucas and Lee 2004). In the NCAP pathway, proteins or ribonucleoprotein complexes are delivered to the plasmodesmata by carriers or chaperones. The carriers or chaperones bind to plasmodesmata docking proteins that induce the plasmodesmata to dilate. This is followed by selective transport of the cargo proteins or ribonucleoprotein complex across the plasmodesmata (Lucas and Lee 2004).

There are two models proposed for viruses whose virion particles move from cell to cell. In the first model, the MPs belonging to como-, nepo-, badna-, and tospoviruses form hollow tubules that extend between cells and serve as conduits for transport of virions (Cheng et al. 1998; Laporte et al. 2003; Storms et al. 2002). The second model was proposed for closteroviruses whose MP is an Hsp70 homolog (called Hsp70h) (Alzhanova et al. 2001). In this model, the major capsid protein forms the virion while the minor capsid protein and Hsp70h form a tail assembly that propels the virion particle into the plasmodesmata. The Hsp70h has ATPase activity which is necessary for tail assembly and cell-to-cell movement. Hsp70h associates with the plasmodesmata and provides the driving force for translocation of the virion through the pore. Plasmodesmal association of Hsp70h triggers tail disassembly which subsequently destabilizes the virion, exposing viral RNA for translation as it moves into the adjacent cell (Alzhanova et al. 2001). 
Most recently, it was shown that TMV replication complexes (VRCs) move from cell to cell via plasmodesmata (Kawakami et al. 2004). These VRCs are membranous vesicles containing the viral replicase, MP, and viral RNA. Once the VRC has moved through the plasmodesmata, replicating viral RNA is released into the adjacent cell (Kawakami et al. 2004).

Plants have developed defense mechanisms to limit the spread of virus infection. RNA silencing is one antiviral defense pathway that blocks the spread of virus infection by targeting viral RNAs for degradation. Virus infection triggers RNA silencing in the initial cell and a signal is produced that moves ahead of the infection front, activating the silencing or defense pathway and preventing further spread of virus infection. To cope with RNA silencing, viruses have evolved suppressor proteins that counter this defense by blocking distinct steps in the silencing pathway (Carrington et al. 2001; Lecellier and Voinnet 2004; Roth et al. 2004). In some cases, RNA silencing suppression is a function of a viral MP. For example, the Potato virus $X$ (PVX) triple gene block (TGB)p1 is a viral MP and a suppressor of RNA silencing which targets the silencing signal and prevents it from spreading (Voinnet et al. 2000). Other examples are the Potyvirus HC-Pro,

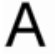

Potato virus $\mathrm{X}$

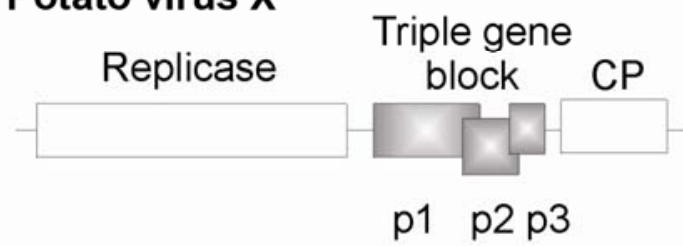

B

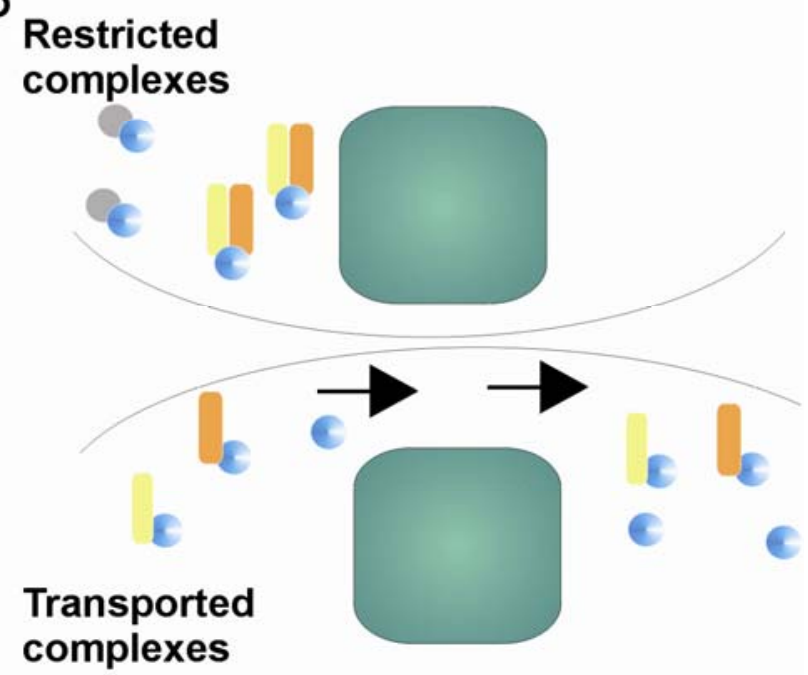

Fig. 1. A, Genome organization of Potato virus $X$ (PVX). Boxes represent open reading frames and lines represent noncoding sequences. The triple gene block (TGB) is highlighted in gray. The replicase and coat protein (CP) genes are indicated above the diagram. The individual TGB proteins are identified below the gray boxes. B, Cell-to-cell movement of PVX TGB and CP proteins in Nicotiana tabacum leaves. Blue spheres represent TGBp1, gray spheres are $\mathrm{CP}$, yellow cylinders are TGBp2, and orange cylinders are TGBp3. In biolistic bombardment studies, TGBp1 moves from cell to cell. Transgenically expressed TGBp1 mediates transport of TGBp2 or TGBp3 (Krishnamurthy et al. 2002). The drawing indicates free TGBp1, TGBp1/TGBp2, and TGBp1/TGBp3 complexes moving through plasmodesmata. TGBp1 does not move in transgenic plants expressing $\mathrm{CP}$ or the combined TGBp2 and TGBp3 (Yang et al. 2000). The drawing indicates TGBp1/CP or TGBp1/TGBp2/TGBp3 complexes are restricted from moving. In $N$. benthamiana, all proteins move through plasmodesmata.
Cucumovirus (CMV) 2b, Hordeivirus $\gamma \mathrm{b}$, and Tombusvirus $19 \mathrm{~K}$ (Anandalakshmi et al. 1998; Havelda et al. 2003; Llave et al. 2000; Park et al. 2004; Qiu et al. 2002; Yelina et al. 2002) which are necessary for virus vascular transport as well as suppressing RNA silencing. Several reports have suggested that virus movement is regulated by RNA silencing and viral suppressors of silencing (Brigneti et al. 1998; Carrington 1999; Carrington 2000; Lecellier and Voinnet 2004).

Common to these models of virus cell-to-cell movement is the ability of the viral MPs to direct transport of viral nucleic acids or virions across plasmodesmata. Recent models of closteroviruses and of TMV movement have linked viral RNA translation or replication to plasmodesmata transport (Alzhanova et al. 2001; Kawakami et al. 2004). We would like to further expand this view of virus transport to include counterdefense measures that are necessary to ensure successful spread of virus infection. In this article, we will explore the mechanism for cell-to-cell movement of PVX. Because PVX TGBp1 is an MP that is also a suppressor of RNA silencing, we will propose a new model for PVX that incorporates its silencing suppressor activity.

\section{PVX and the triple gene block.}

PVX is a single-strand, positive-sense RNA virus. It is the type species of the Potexvirus genus (Huisman et al. 1988) and serves as a model system to study virus replication, cell-to-cell movement, and virus-induced gene silencing (Batten et al. 2003). The PVX genome contains five overlapping open reading frames (ORFs) encoding the viral replicase, the TGB, and the viral coat protein (CP) (Fig. 1A). The TGB encode three MPs named TGBp1, TGBp2, and TGBp3 (Beck et al. 1991; Verchot et al. 1998). The viral CP is required for genome encapsidation and virus cell-to-cell movement (Cruz et al. 1996; Fedorkin et al. 2001; Forster et al. 1992).

TGBp1 is a multifunctional protein that increases plasmodesmal permeability for virus cell-to-cell movement, has RNA helicase activity, promotes translation of virion RNAs, and is a suppressor of gene silencing (Atabekov et al. 2000; Kalinina et al. 2002; Rouleau et al. 1994; Voinnet et al. 2000). TGBp1 forms oligomers and inclusion bodies in infected cells (Davies et al. 1993; Hsu et al. 2004).

TGBp2 and TGBp3 associate with the endoplasmic reticulum (ER) (Krishnamurthy et al. 2003; Mitra et al. 2003). TGBp2 has two transmembrane domains and TGBp3 has one transmembrane domain near the N-terminus. Mutations disrupting ER association of either TGBp2 or TGBp3 disrupt virus movement, suggesting that ER association of these two proteins is important (Krishnamurthy et al. 2003; Mitra et al. 2003). There also is evidence that TGBp2 and TGBp3 play roles in virus infection that go beyond membrane binding. Mutations outside the transmembrane domains of TGBp2 or TGBp3 either reduced or eliminated virus cell-to-cell movement (Krishnamurthy et al. 2003; Mitra et al. 2003). These mutations might interfere with the ability of TGBp2 or TGBp3 to interact with TGBp1, CP, or with cellular factors needed for virus movement.

\section{TGBp1 RNA helicase activity and plasmodesmata transport.}

The role of NTP hydrolysis or RNA helicase activity as a driving force propelling virus through the plasmodesmata has been the subject of investigation for TGB-containing and some non-TGB-containing viruses. Closteroviruses are among the non-TGB-containing viruses that require ATP hydrolysis by its MP, Hsp70h, for virus movement through plasmodesmata (Alzhanova et al. 2001). The helicase domain of the TMV replicase is also necessary for virus cell-to-cell movement (Hirashima and Watanabe 2003). 
The Potexvirus TGBp1 has seven NTPase/helicase domains and belongs to superfamily I RNA helicases (Morozov et al. 1999). Two of the motifs are canonical NTPase motifs, GKS and DEY, which provide NTP and $\mathrm{Mg}^{2+}$ binding, both required for RNA helicase activity (Morozov et al. 1999). Mutations eliminating the TGBp1 GKS or DEY motifs were reported to inhibit virus cell-to-cell movement as well as the ability of TGBp1 to increase plasmodesmal permeability (Angell et al. 1996; Lough et al. 1998; Morozov et al. 1999). A recent study has shown that some mutations eliminating the DEY motif also affect protein subcellular targeting (Howard et al. 2004); therefore, we cannot yet be certain of the specific role NTPase or helicase activity has in Potexvirus movement.

TGBp1 helicase activity might play a role in unwinding virion particles and in regulating viral RNA translation. When low concentrations of TGBp1 are mixed with PVX virions, TGBp1 is bound to one end of the virion (Kiselyova et al. 2003; Rodionova et al. 2003). Increasing concentrations of the Potexvirus TGBp1 can destabilize the helical virion particle, resulting in TGBp1-PVX complexes that resemble "beads on a string" (Kiselyova et al. 2003). In other studies, translation of virion-derived RNA was stimulated in vitro by adding excess TGBp1 to the translation system (Atabekov et al. 2001; Rodionova et al. 2003). If plasmodesmata transport of TGBp1 is linked to translation of virion-derived RNAs, then a model for Potexvirus cell-to-cell movement might resemble the model for closteroviruses in which virion particles are unwound during plasmodesmata transport, presenting viral RNAs to the translation machinery in the recipient cell.

Because of the range of activities attributed to TGBp1, it might mimic eukaryotic RNA helicases known to unwind ribonucleoprotein complexes, stimulate translation, or promote nucleocytoplasmic trafficking (Fairman et al. 2004; Linder 2003; Rout et al. 2000). For example, TGBp1 might function similarly to eIF4A and Ded1p, which are RNA helicases that promote translation initiation in yeast and higher organisms (Linder 2003). In yeast, a mutant of Ded1p was shown to selectively inhibit translation of Brome mosaic virus (BMV) RNA2 and affect virus replication, suggesting that Ded1p might play a regulatory role in the BMV infection cycle in addition to its role in translation initiation (Noueiry et al. 2000). Although BMV uses cellular helicases to regulate genomic RNA translation, it is possible that PVX relies on TGBp1 to promote selective translation of viral genomic and subgenomic RNAs.

It is tempting to hypothesize that TGBp1 might play a role in plasmodesmata transport similar to the role of RNA helicases in nucleocytoplasmic trafficking of RNAs. In yeast, Rat8p/Dbp5p is an RNA helicase that occurs on the cytoplasmic side of the nuclear pore (Fairman et al. 2004; Rollenhagen et al. 2004; Rout et al. 2000). Rat8p/Dbp5p functions to strip off ribonucleoprotein complexes, allowing the proteins involved in trafficking to return to the nucleus for additional mRNA export. This is particularly important during heat shock, when rapid and efficient export of heat shock mRNAs is important (Rollenhagen et al. 2004). TGBp1 might act to unwind virions or strip CP and MPs off the viral RNA following plasmodesmata transport, thereby allowing the exchange of proteins needed to provide more rounds of RNA export (Fairman et al. 2004). If the normal transport of cellular macromolecules is restricted due to mounting cellular defenses or stress, TGBp1 might be necessary to ensure plasmodesmal transport of viral RNAs under normal and adverse conditions.

\section{Protein movement through plasmodesmata.}

The Potexvirus TGBp1 was shown to increase plasmodesmata permeability in TGBp1-expressing transgenic Nicotiana benthamiana and N. tabacum (Howard et al. 2004; Lough et al. 2000; Lough et al. 1998) and in trichome cells of N. clevelandii leaves (Angell et al. 1996). In later studies, the role of TGBp2 in gating plasmodesmata was a subject of controversy because of experiments showing that TGBp2 can promote cellto-cell movement of GFP in trans in $N$. benthamiana leaves (Tamai and Meshi 2001). To address this controversy, experiments were conducted in a range of PVX host plants to determine whether these observations were unique to $N$. benthamiana or were real properties of TGBp2. GFP was fused to each of the TGB and CP genes and biolistic techniques were used to deliver plasmids to leaf epidermal cells. Cell-to-cell movement of GFP-TGBp2, GFP-TGBp3, and GFP-CP was observed in $N$. benthamiana plants (Krishnamurthy et al. 2002). However, only GFP-TGBp1 moves from cell to cell in N. tabacum, N. clevelandii, and Lycopersicon esculentum leaves (Howard et al. 2004; Krishnamurthy et al. 2002, 2003) (Fig. 1B). In transgenic N. tabacum expressing TGBp1, cellto-cell movement of GFP-TGBp2 and GFP-TGBp3 was observed. In transgenic $N$. tabacum expressing the combined TGBp2 and TGBp3, movement of GFP-TGBp1 was restricted (Fig. 1B). The ability of GFP-TGBp1, GFP-TGBp2, GFPTGBp3, and GFP-CP to increase plasmodesmal permeability in $N$. benthamiana leaves was unique to this host, suggesting that a wider range of proteins move through plasmodesmata in $N$. benthamiana leaves than in many other plant species. Thus, in most PVX hosts, TGBp1 is the primary viral factor to increase plasmodesmal permeability (Howard et al. 2004).

The role of Potexvirus CP in plasmodesmata transport also was a source of controversy. As mentioned previously, microinjection studies suggested that TGBp1 and CP bound to RNA moves through plasmodesmata (Oparka et al. 1999) However, electron and fluorescence microscopic studies revealed that free PVX CP accumulates inside plasmodesmata and that transgenically expressed PVX CP restricts cell-to-cell movement of GFP-TGBp1 in N. tabacum. Conceivably, CP moves from cell to cell only when it is part of a ribonucleoprotein complex with TGBp1 and viral RNA or when TGBp1 is associated with virions. If TGBp1 functions similarly to the Closterovirus Hsp70h MP, unwinding virion particles as they exit the plasmodesmata, as suggested earlier, then residual $\mathrm{CP}$ either returns to the cell for additional viral RNA transport or accumulates inside the pore. It is tempting to speculate that accumulation of $\mathrm{CP}$ inside the pore might regulate the ability of TGBp1 to maintain an increased SEL. In this latter scenario, CP would recognize receptors within the plasmodesmata that also interact with TGBp1. CP could act behind the infection front to dislodge any TGBp1 that might be associated with the pore, thus restoring the plasmodesmata to its natural physiological state. Further research is needed to characterize the role of $\mathrm{CP}$ in virus cellto-cell movement.

The ability of TGBp1 to move from cell to cell might have purposes beyond directing viruses across the plasmodesmata. Cell-to-cell movement of TGBp1 might be important for its role in suppressing RNA silencing. If RNA silencing is a host defense mechanism restricting the spread of virus infection, then TGBp1 could move from cell to cell, ahead of the infection front, as a means to counter RNA silencing. This idea is supported by recent evidence that suppression of RNA silencing by TGBp1 is important for virus movement (D. C. Baulcombe, personal communication). It is worth further investigation to determine whether plasmodesmata transport of TGBp1 is important for suppressing RNA silencing. Another protein that suppresses RNA silencing and moves from cell to cell is the Potyvirus HC-Pro (Rojas et al. 1997). Because HC-Pro is important for vascular and not cell-to-cell viral transport (Cronin et al. 1995), its own ability to move through plasmodesmata 


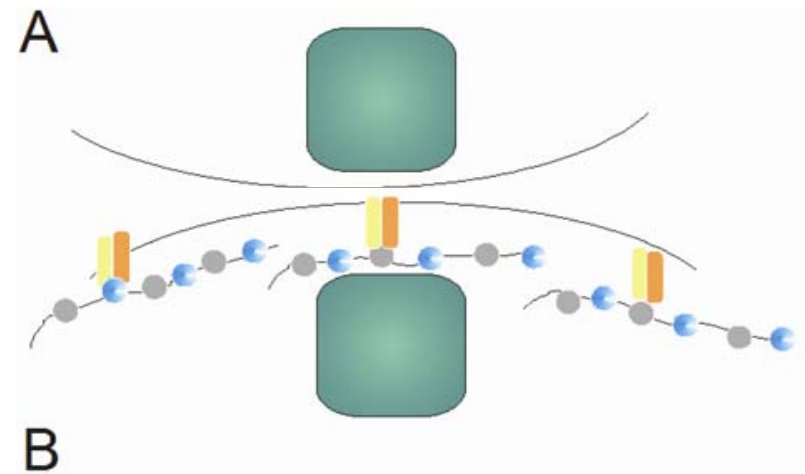

1. Early: Protein transport and docking

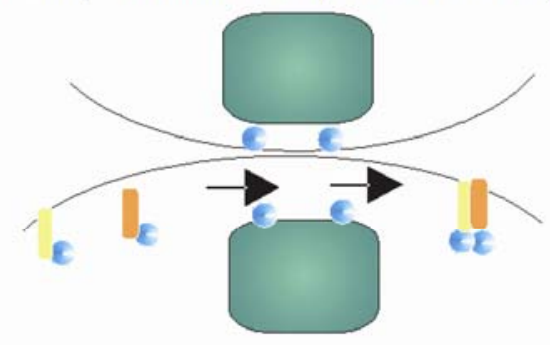

2. Middle: TGBp1-PVX transport..

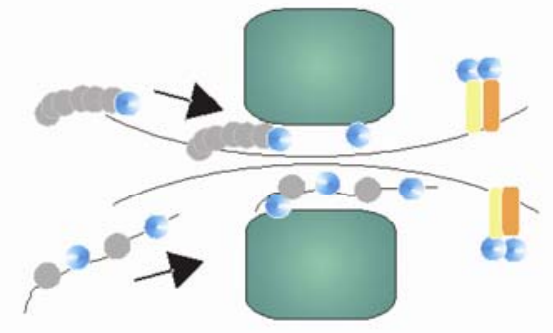

3. Late: TGBp1-PVX docking followed by translation

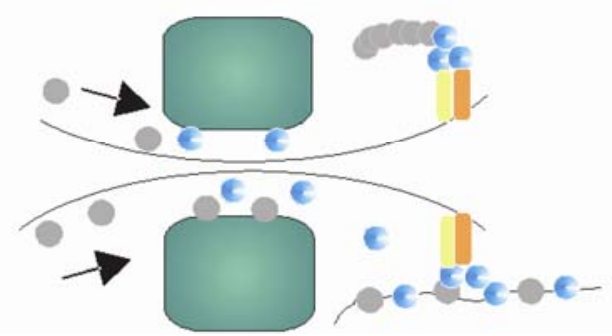

Fig. 2. Two models describing different mechanisms for potexvirus cell-tocell movement. Blue spheres represent triple gene block (TGB)p1, gray spheres are coat protein (CP), yellow cylinders are TGBp2, and orange cylinders are TGBp3. A, Model first proposed by Lough and associates (1998) in which a ribonucleoprotein complex consisting of TGBp1, CP, and viral RNA is bound by TGBp2 and TGBp3 to the endoplasmic reticulum (ER). The complex moves along the ER toward and through the plasmodesmata. $\mathbf{B}$, Model based on data obtained in studies of Potato virus $X$ (PVX) in Nicotiana tabacum. The process of virus movement has early, middle, and late events that are numbered 1, 2, and 3. In early events, TGBp1 increases plasmodesmal permeability. Some TGBp1 molecules move into neighboring cells where they suppress RNA silencing ahead of virus infection. Some TGBp1 molecules bind either TGBp 2 or TGBp 3 and these separate complexes move through the plasmodesmata. The TGB proteins form a membranebound complex in neighboring cells that is called the "docking complex". In the middle events, TGBp1-PVX virions or ribonucleoprotein complexes move across plasmodesmata. TGBp1 provides the driving force propelling PVX from cell to cell. In the late events, TGBp1-PVX complexes associate with the membrane-bound complex by TGBp1-TGBp1 interactions. The TGBp1 oligomers within the complex enhance translation of the viral RNA. Some free $\mathrm{CP}$ is retained with the plasmodesmata, dislodging TGBp1 molecules associated with the pore and restoring the pore to its natural state. might be related to its role in suppressing RNA silencing. HCPro is a silencing suppressor that blocks accumulation of short interfering RNAs (Llave et al. 2000; Mallory et al. 2002); therefore, its own ability to move from cell to cell might allow $\mathrm{HC}$ Pro to act ahead of virus infection, limiting siRNAs the effects of the RNA silencing signal in target tissues.

\section{Old and new models for movement of potexviruses.}

Purified White clover mosaic virus (WClMV) proteins and viral RNAs were co-injected into leaf cells and their ability to move through plasmodesmata was recorded (Lough et al. 1998). These early results led to a model in which the Potexvirus TGBp1 and CP carries viral RNA across plasmodesmata (Fig. 2A) (Lough et al. 1998, 2000). This ribonucleoprotein "movement complex" was supported by in vitro RNA binding gel mobility-shift assays which showed the PVX TGBp1 and CP together bind RNA (Lough et al. 1998, 2000). Further experiments revealed that the $\mathrm{C}$-terminal region of the PVX CP plays a role in virus movement independent of encapsidation (Fedorkin et al. 2001). In addition, the Potato virus $Y$ (PVY) CP complemented cell-to-cell movement of PVX CP-defective mutants. The PVY CP did not encapsidate the PVX genome, suggesting that the PVX and PVY CPs play a role in virus movement that is distinct from their role in encapsidation (Fedorkin et al. 2000).

The same model suggested that the movement complex moves within the infected cell toward the plasmodesmata along either the ER or the cytoskeleton (Lough et al. 1998, 2000). Evidence that TGBp2 and TGBp3 bind to the ER (Krishnamurthy et al. 2003; Mitra et al. 2003) led to suggestions that these proteins were membrane anchors trafficking the complex from cell to cell. In further experiments, the PVX $\mathrm{CP}$ interacted with microtubules, supporting the model in which the movement complex uses the cytoskeleton as a track to move from cell to cell (Serazev et al. 2003). The model of a ribonucleoprotein complex tracking along the ER or cytoskeleton paralleled contemporaneous models describing cell-to-cell movement of TMV, RCNMV, BDMV, Cauliflower mosaic virus (CaMV), Squash leaf curl virus (SqLCV), and Tomato spotted wilt virus (TSWV) (Citovsky et al. 1990, 1991; Citovsky and Zambryski 1991; Giesman-Cookmeyer and Lommel 1993; Qin et al. 1998; Rojas et al. 1998; Soellick et al. 2000). However, recent evidence suggesting that cell-to-cell movement of the Potexvirus TGB and CP proteins is host dependent, that TGBp1 associates with virions as well as a ribonucleoprotein complex containing $\mathrm{CP}$, that TGBp1 promotes virus translation, and that suppression of RNA silencing is linked to virus movement leads us to propose a new, more elaborate model for Potexvirus movement.

This new model has early, middle, and late events (Fig. 2B). During the early events, TGBp1 moves from cell to cell and positions itself inside plasmodesmata where it can increase plasmodesmal SEL for virus cell-to-cell transport. Some populations of TGBp1 interact with either TGBp2 or TGBp3 and direct them separately across the plasmodesmata. TGBp1 might suppress RNA silencing in neighboring cells as it moves ahead of the invading virus. Because silencing is an antiviral defense, it is important for a successful viral infection that TGBp1 acts in cells ahead of the invading virus. To speculate further, TGBp1/TGBp2 or TGBp1/TGBp3 complexes might move into neighboring cells where these complexes act in concert to suppress silencing and other host defenses. This might be an important prelude to promote virus movement, preparing the recipient cells for virus infection. In the neighboring cells, TGBp2 and TGBp3 bind to ER membranes near plasmodesmata, tethering TGBp1. The strength of the TGBp1-TGBp1 interactions holds together the membrane-bound "docking complex". 
In the middle events, virus moves across the plasmodesmata into neighboring cells either as a virion particle or a ribonucleoprotein complex. TGBp1 might associate with virion particles to transport them across the plasmodesmata. Alternatively, a ribonucleoprotein complex containing TGBp1, CP, and viral RNA moves across the plasmodesmata. Based on structural analyses of the TGBp1-PVX complexes that were described earlier (Kiselyova et al. 2003), we do not yet know the nature of the complex that moves through the plasmodesmata.

In the late events, TGBp1-PVX or TGBp1-CP-RNA is anchored to the ER by the docking complex in the neighboring cell. It is the association of TGBp1 oligomers with TGBp2 and TGBp3 which builds the complex (Fig. 2B). Based on previous in vitro studies, the presence of excess TGBp1, perhaps in the form of TGBp1 oligomers, unwinds PVX virions or the ribonucleoprotein complexes, making viral RNA available for translation. Virus replication in the neighboring cell follows translation. It is generally accepted that virus replication is membrane associated; therefore, this membrane-bound movement complex also might be a center for replication of viral RNA following translation. Finally, some free CP displaces TGBp1 within the plasmodesmata, restoring the plasmodesmata to its resting state. TGBp1 might be recycled to provide either more rounds of RNA transport or to spread beyond the infection front suppressing RNA silencing.

\section{DISCUSSION}

\section{Broad perspective.}

There are at least eight virus genera containing TGBs (Morozov and Solovyev 2003). Extensive amino acid sequence comparisons indicate that the TGB-containing viruses can be distinguished as two classes: potex-like and hordei-like (Morozov and Solovyev 2003). The potex-like viruses have monopartite genomes, are filamentous, require the $\mathrm{CP}$ for virus cell-to-cell movement, and include the carla-, allexi-, and foveaviruses. The hordei-like viruses are multi-partite, have rodshaped virion particles, do not require the $\mathrm{CP}$ for cell-to-cell movement, and include pomo-, peclu-, and benyviruses. A detailed review of the phylogenetic relationships among the TGB containing viruses is provided elsewhere (Morozov and Solovyev 2003).

There has been extensive research on the TGB of many viruses and there are often conflicting data. This raises the question: Can one model describe the mechanism for all TGB-containing viruses? It is likely that two models are needed and that the cell-to-cell movement mechanisms are likely to fall into similar potex-like and hordei-like classes. This is due to different properties of the TGB proteins. The hordei-like TGBp1s are larger than the potex-like TGBp1s, ranging from 41 to 63 $\mathrm{kDa}$ in size. The hordei-like TGBp1s have N-terminal extensions that have additional RNA binding capacity that is not present in Potexvirus TGBp1 proteins (Bleykasten et al. 1996; Cowan et al. 2002; Donald et al. 1997; Erhardt et al. 2000; Kalinina et al. 2001; Morozov and Solovyev 2003; Solovyev et al. 1996). Because the hordei-like viruses do not require the viral CPs for cell-to-cell movement, it is reasonable to suggest the N-terminal RNA-binding extension provides the same RNA-binding activity that the Potexvirus CP provides.

Other important differences among the potex-like and hordei-like viruses include: i) the Potexvirus TGBp1 has the ability to increase plasmodesmal permeability and move from cell to cell, whereas the hordei-like TGBp1 depends on TGBp2 and TGBp3 to carry it across plasmodesmata (Cowan et al. 2002; Erhardt et al. 1999, 2000; Lawrence and Jackson 2001); ii) the Potexvirus TGBp1 is a suppressor of gene silencing, whereas hordei-like viruses encode another protein that is a si- lencing suppressor (Dunoyer et al. 2002; Voinnet et al. 1999); and iii) all hordei-like viruses are transmitted by plasmodiophorids and there is a possibility that the TGB of hordei-like viruses contributes to viral transmission (Campbell 1996; Dessens and Meyer 1996; Tamada et al. 1996). A recent study of the Furovirus, Soilborne wheat mosaic virus (SBWMV), implicates the viral MP in mediating virus transmission from the plasmodiophorid vector (Polymyxa graminis) into the host (Driskel et al. 2004). This raises the possibility that TGB-containing viruses having similar vectors also might employ viral MPs to mediate transfer into plant hosts.

The model proposed in this article (Fig. 2B) is not written to describe all TGB-containing viruses but likely applies to potex- and potex-like viruses. The early model that was proposed by Lough and associates (1998) (Fig. 2A) most closely reflects the data obtained in studies of hordei- and hordei-like viruses. Thus, in spite of the similarities among TGB-containing viruses, there may be enough differences to warrant different models.

\section{Conclusion.}

Recent discoveries that TGBp1 is a suppressor of silencing and enhances viral RNA translation suggest that countering defense and viral genome expression might be linked to viral plasmodesmata transport. It is reasonable to suggest that suppressing RNA silencing might be an important early step toward promoting virus cell-to-cell movement. Moreover, evidence that TGBp1 is multifunctional leads us to wonder if TGBp2, TGBp3, or CP have additional roles in viral infection or in countering plant defenses. Thus, cell-to-cell movement of TGBp1-TGBp2 or TGBp1-TGBp3 complexes might serve purposes distinct from facilitating virus cell-to-cell movement.

Recent models proposed for movement of closteroviruses and for TMV link virus translation or replication with the cellto-cell movement mechanism (Alzhanova et al. 2001; Kawakami et al. 2004). This new, elaborate model for potexviruses links viral RNA translation and counterdefense with virus transport. These models suggest that plasmodesmata transport of viral nucleic acids does not occur in isolation from other events in the infection cycle. What happens to the nucleic acid after it moves through the plasmodesmata might determine the mechanism by which it is transported from cell to cell.

\section{ACKNOWLEDGMENTS}

Special thanks to J. C. Carrington and G. Schoenknecht for critical review of the manuscript. This work was supported in part by the Oklahoma Agriculture Experiment Station under the project H-2371. The project was funded by the National Science Foundation Integrative Plant Biology Program Award IBM-9982552.

\section{LITERATURE CITED}

Agranovsky, A. A., Folimonov, A. S., Folimonova, S., Morozov, S., Schiemann, J., Lesemann, D., and Atabekov, J. G. 1998. Beet yellows closterovirus HSP70-like protein mediates the cell-to-cell movement of a potexvirus transport-deficient mutant and a hordeivirus-based chimeric virus. J. Gen. Virol. 79:889-895.

Alzhanova, D. V., Napuli, A. J., Creamer, R., and Dolja, V. V. 2001. Cellto-cell movement and assembly of a plant closterovirus: Roles for the capsid proteins and Hsp70 homolog. EMBO (Eur. Mol. Biol. Organ.) J. 20:6997-7007.

Anandalakshmi, R., Pruss, G. J., Ge, X., Marathe, R., Mallory, A. C., Smith, T. H., and Vance, V. B. 1998. A viral suppressor of gene silencing in plants. Proc. Natl. Acad. Sci. U.S.A. 95:13079-13084.

Angell, S. M., Davies, C., and Baulcombe, D. C. 1996. Cell-to-cell movement of Potato virus $X$ is associated with a change in the size-exclusion limit of plasmodesmata in trichome cells of Nicotiana clevelandii. Virology 216:197-201.

Atabekov, J. G., Rodionova, N. P., Karpova, O. V., Kozlovsky, S. V., Novikov, V. K., and Arkhipenko, M. V. 2001. Translational activation of 
encapsidated Potato virus $X$ RNA by coat protein phosphorylation. Virology 286:466-474.

Atabekov, J. G., Rodionova, N. P., Karpova, O. V., Kozlovsky, S. V., and Poljakov, V. Y. 2000. The movement protein-triggered in situ conversion of Potato virus $X$ virion RNA from a nontranslatable into a translatable form. Virology 271:259-263.

Batten, J. S., Yoshinar, S., and Hemenway, C. 2003. Potato virus X: A model system for virus replication, movement, and gene expression. Mol. Plant Pathol. 4:125-131.

Beck, D. L., Guilford, P. J., Voot, D. M., Andersen, M. T., and Forster, R L. 1991. Triple gene block proteins of white clover mosaic potexvirus are required for transport. Virology 183:695-702

Bleykasten, C., Gilmer, D., Guilley, H., Richards, K. E., and Jonard, G. 1996. Beet necrotic yellow vein virus $42 \mathrm{kDa}$ triple gene block protein binds nucleic acid in vitro. J. Gen. Virol. 77:889-897.

Brigneti, G., Voinnet, O., Li, W. X., Ji, L. H., Ding, S. W., and Baulcombe, D. C. 1998. Viral pathogenicity determinants are suppressors of transgene silencing in Nicotiana benthamiana. EMBO (Eur. Mol. Biol. Organ.) J. 17:6739-6746.

Campbell, R. N. 1996. Fungal transmission of plant viruses. Annu. Rev. Phytopathol. 34:87-108.

Carrington, J. C. 1999. Reinventing plant virus movement. Trends Microbiol. 7:312-313

Carrington, J. C. 2000. RNA silencing. Moving targets. Nature 408:150151

Carrington, J. C., Kasschau, K. D., and Johansen, L. K. 2001. Activation and suppression of RNA silencing by plant viruses. Virology 281:1-5.

Cheng, C. P., Tzafrir, I., Lockhart, B. E., and Olszewski, N. E. 1998. Tubules containing virions are present in plant tissues infected with Commelina yellow mottle badnavirus. J. Gen. Virol. 79:925-929.

Citovsky, V., Knorr, D., Schuster, G., and Zambryski, P. 1990. The P30 movement protein of Tobacco mosaic virus is a single-strand nucleic acid binding protein. Cell 60:637-647.

Citovsky, V., Knorr, D., and Zambryski, P. 1991. Gene I, a potential cellto-cell movement locus of Cauliflower mosaic virus, encodes an RNAbinding protein. Proc. Natl. Acad. Sci. U.S.A. 88:2476-2480.

Citovsky, V., Wong, M. L., Shaw, A. L., Prasad, B. V., and Zambryski, P. 1992. Visualization and characterization of Tobacco mosaic virus movement protein binding to single-stranded nucleic acids. Plant Cell 4:397411

Citovsky, V., and Zambryski, P. 1991. How do plant virus nucleic acids move through intercellular connections? Bioassays 13:373-379.

Cowan, G. H., Lioliopoulou, F., Ziegler, A., and Torrance, L. 2002. Subcellular localisation, protein interactions, and RNA binding of Potato mop-top virus triple gene block proteins. Virology 298:106-115.

Crawford, K. M., and Zambryski, P. C. 2001. Non-targeted and targeted protein movement through plasmodesmata in leaves in different developmental and physiological states. Plant Physiol. 125:1802-1812.

Cronin, S., Verchot, J., Haldeman-Cahill, R., Schaad, M. C., and Carrington, J. C. 1995. Long-distance movement factor: A transport function of the potyvirus helper component proteinase. Plant Cell 7:549-559.

Cruz, S. S., Chapman, S., Roberts, A. G., Roberts, I. M., Prior, D. A., and Oparka, K. J. 1996. Assembly and movement of a plant virus carrying a green fluorescent protein overcoat. Proc. Natl. Acad. Sci. U.S.A. 93:6286-6290.

Davies, C., Hills, G., and Baulcombe, D. C. 1993. Sub-cellular localization of the 25-kDa protein encoded in the triple gene block of Potato virus $X$. Virology 197:166-175.

Derrick, P. M., Barker, H., and Oparka, K. J. 1992. Increase in plasmodesmatal permeability during cell-to-cell spread of Tobacco rattle virus from individually inoculated cells. Plant Cell 4:1405-1412.

Dessens, J. T., and Meyer, M. 1996. Identification of structural similarities between putative transmission proteins of Polymyxa and Spongospora transmitted bymoviruses and furoviruses. Virus Genes 12:95-99.

Ding, B., Li, Q., Nguyen, L., Palukaitis, P., and Lucas, W. J. 1995. Cucumber mosaic virus 3 a protein potentiates cell-to-cell trafficking of CMV RNA in tobacco plants. Virology 207:345-353.

Donald, R. G., Lawrence, D. M., and Jackson, A. O. 1997. The Barley stripe mosaic virus 58-kilodalton beta(b) protein is a multifunctional RNA binding protein. J. Virol. 71:1538-1546.

Driskel, B. A., Doss, P., Littlefield, L. J., Walker, N. R., and VerchotLubicz, J. 2004. Soilborne wheat mosaic virus movement protein and RNA and Wheat spindle streak mosaic virus coat protein accumulate inside resting spores of their vector, Polymyxa graminis. Mol. PlantMicrobe Interact. 17:739-748.

Dunoyer, P., Pfeffer, S., Fritsch, C., Hemmer, O., Voinnet, O., and Richards, K. E. 2002. Identification, subcellular localization and some properties of a cysteine-rich suppressor of gene silencing encoded by Peanut clump virus. Plant J. 29:555-567.

Erhardt, M., Morant, M., Ritzenthaler, C., Stussi-Garaud, C., Guilley, H.,
Richards, K., Jonard, G., Bouzoubaa, S., and Gilmer, D. 2000. P42 movement protein of Beet necrotic yellow vein virus is targeted by the movement proteins P13 and P15 to punctate bodies associated with plasmodesmata. Mol. Plant-Microbe Interact. 13:520-528.

Erhardt, M., Stussi-Garaud, C., Guilley, H., Richards, K. E., Jonard, G., and Bouzoubaa, S. 1999. The first triple gene block protein of Peanut clump virus localizes to the plasmodesmata during virus infection. Virology 264:220-229.

Fairman, M. E., Maroney, P. A., Wang, W., Bowers, H. A., Gollnick, P., Nilsen, T. W., and Jankowsky, E. 2004. Protein displacement by DExH/D "RNA helicases" without duplex unwinding. Science 304:730734.

Fedorkin, O., Solovyev, A., Yelina, N., Zamyatnin, A., Jr., Zinovkin, R., Makinen, K., Schiemann, J., and Morozov, S. Y. 2001. Cell-to-cell movement of Potato virus $X$ involves distinct functions of the coat protein. J. Gen. Virol. 82:449-458.

Fedorkin, O. N., Merits, A., Lucchesi, J., Solovyev, A. G., Saarma, M., Morozov, S. Y., and Makinen, K. 2000. Complementation of the movement-deficient mutations in Potato virus $X$ : Potyvirus coat protein mediates cell-to-cell trafficking of C-terminal truncation but not deletion mutant of potexvirus coat protein. Virology 270:31-42.

Forster, R. L., Beck, D. L., Guilford, P. J., Voot, D. M., Van Dolleweerd, C. J., and Andersen, M. T. 1992. The coat protein of white clover mosaic potexvirus has a role in facilitating cell-to-cell transport in plants. Virology 191:480-484.

Fujita, M., Mise, K., Kajiura, Y., Dohi, K., and Furusawa, I. 1998. Nucleic acid-binding properties and subcellular localization of the 3 a protein of brome mosaic bromovirus. J. Gen. Virol. 79:1273-1280.

Fujiwara, T., Giesman-Cookmeyer, D., Ding, B., Lommel, S. A., and Lucas, W. J. 1993. Cell-to-cell trafficking of macromolecules through plasmodesmata potentiated by the Red clover necrotic mosaic virus movement protein. Plant Cell 5:1783-1794.

Giesman-Cookmeyer, D., and Lommel, S. A. 1993. Alanine scanning mutagenesis of a plant virus movement protein identifies three functional domains. Plant Cell 5:973-982.

Giesman-Cookmeyer, D., Silver, S., Vaewhongs, A. A., Lommel, S. A., and Deom, C. M. 1995. Tobamovirus and dianthovirus movement proteins are functionally homologous. Virology 213:38-45.

Gilbertson, R. L., Sudarshana, M., Jiang, H., Rojas, M. R., and Lucas, W. J. 2003. Limitations on geminivirus genome size imposed by plasmodesmata and virus-encoded movement protein: Insights into DNA trafficking. Plant Cell 15:2578-2591.

Havelda, Z., Hornyik, C., Crescenzi, A., and Burgyan, J. 2003. In situ characterization of Cymbidium ringspot tombusvirus infection-induced posttranscriptional gene silencing in Nicotiana benthamiana. J. Virol. 77:6082-6086.

Hehnle, S., Wege, C., and Jeske, H. 2004. Interaction of DNA with the movement proteins of geminiviruses revisited. J. Virol. 78:7698-7706.

Hirashima, K., and Watanabe, Y. 2003. RNA helicase domain of tobamovirus replicase executes cell-to-cell movement possibly through collaboration with its nonconserved region. J. Virol. 77:12357-12362.

Howard, A. R., Heppler, M. L., Ju, H.-J., Krishnamurthy, K., Payton, M. E., and Verchot-Lubicz, J. 2004. Potato virus X TGBp1 induces plasmodesmata gating and moves between cells in several host species whereas CP moves only in Nicotiana benthamiana leaves. Virology 328:185-197.

Hsu, H. T., Hsu, Y. H., Bi, I. P., Lin, N. S., and Chang, B. Y. 2004. Biological functions of the cytoplasmic TGBp1 inclusions of bamboo mosaic potexvirus. Arch. Virol. 149:1027-1035.

Huisman, M. J., Linthorst, H. J., Bol, J. F., and Cornelissen, J. C. 1988. The complete nucleotide sequence of Potato virus $X$ and its homologies at the amino acid level with various plus-stranded RNA viruses. J. Gen. Virol. 69:1789-1798

Itaya, A., Woo, Y. M., Masuta, C., Bao, Y., Nelson, R. S., and Ding, B. 1998. Developmental regulation of intercellular protein trafficking through plasmodesmata in tobacco leaf epidermis. Plant Physiol. 118:373-385.

Ivanov, K. I., Ivanov, P. A., Timofeeva, E. K., Dorokhov, Y. L., and Atabekov, J. G. 1994. The immobilized movement proteins of two tobamoviruses form stable ribonucleoprotein complexes with full-length viral genomic RNA. FEBS (Fed. Eur. Biol. Soc.) Lett. 346:217-220.

Kalinina, N. O., Rakitina, D. A., Yelina, N. E., Zamyatnin, A. A., Jr., Stroganova, T. A., Klinov, D. V., Prokhorov, V. V., Ustinova, S. V., Chernov, B. K., Schiemann, J., Solovyev, A. G., and Morozov, S. Y. 2001. RNA-binding properties of the $63 \mathrm{kDa}$ protein encoded by the triple gene block of poa semilatent hordeivirus. J. Gen. Virol. 82:2569-2578.

Kalinina, N. O., Rakitina, D. V., Solovyev, A. G., Schiemann, J., and Morozov, S. Y. 2002. RNA helicase activity of the plant virus movement proteins encoded by the first gene of the triple gene block. Virology 296:321-329. 
Kawakami, S., Watanabe, Y., and Beachy, R. N. 2004. Tobacco mosaic virus infection spreads cell to cell as intact replication complexes. Proc. Natl. Acad. Sci. U.S.A. 101:6291-6296.

Kiselyova, O. I., Yaminsky, I. V., Karger, E. M., Frolova, O. Y., Dorokhov, Y. L., and Atabekov, J. G. 2001. Visualization by atomic force microscopy of Tobacco mosaic virus movement protein-RNA complexes formed in vitro. J. Gen. Virol. 82:1503-1508.

Kiselyova, O. I., Yaminsky, I. V., Karpova, O. V., Rodionova, N. P. Kozlovsky, S. V., Arkhipenko, M. V., and Atabekov, J. G. 2003. AFM study of Potato virus $X$ disassembly induced by movement protein. J. Mol. Biol. 332:321-325.

Krishnamurthy, K., Heppler, M., Mitra, R., Blancaflor, E., Payton, M., Nelson, R. S., and Verchot-Lubicz, J. 2003. The Potato virus X TGBp3 protein associates with the ER network for virus cell-to-cell movement. Virology 309:135-151.

Krishnamurthy, K., Mitra, R., Payton, M. E., and Verchot-Lubicz, J. 2002. Cell-to-cell movement of the PVX $12 \mathrm{~K}, 8 \mathrm{~K}$, or coat proteins may depend on the host, leaf developmental stage, and the PVX $25 \mathrm{~K}$ protein. Virology 300:269-281.

Laporte, C., Vetter, G., Loudes, A. M., Robinson, D. G., Hillmer, S., Stussi-Garaud, C., and Ritzenthaler, C. 2003. Involvement of the secretory pathway and the cytoskeleton in intracellular targeting and tubule assembly of Grapevine fanleaf virus movement protein in tobacco BY-2 cells. Plant Cell 15:2058-2075.

Lawrence, D. M., and Jackson, A. O. 2001. Interactions of the TGB1 protein during cell-to-cell movement of Barley stripe mosaic virus. J. Virol. 75:8712-8723.

Lecellier, C. H., and Voinnet, O. 2004. RNA silencing: No mercy for viruses? Immunol. Rev. 198:285-303.

Linder, P. 2003. Yeast RNA helicases of the DEAD-box family involved in translation initiation. Biol. Cell 95:157-167.

Llave, C., Kasschau, K. D., and Carrington, J. C. 2000. Virus-encoded suppressor of posttranscriptional gene silencing targets a maintenance step in the silencing pathway. Proc. Natl. Acad. Sci. U.S.A. 97:13401-13406.

Lough, T. J., Netzler, N. E., Emerson, S. J., Sutherland, P., Carr, F., Beck, D. L., Lucas, W. J., and Forster, R. L. 2000. Cell-to-cell movement of potexviruses: Evidence for a ribonucleoprotein complex involving the coat protein and first triple gene block protein. Mol. Plant-Microbe Interact. 13:962-974.

Lough, T. J., Shash, K., Xoconostle-Cázares, B., Hofstra, K. R., Beck, D. L., Balmori, E., Forster, R. L. S., and Lucas, W. J. 1998. Molecular dissection of the mechanism by which potexvirus triple gene block proteins mediate cell-to-cell transport of infectious RNA. Mol. PlantMicrobe Interact. 11:801-814.

Lucas, W. J., and Lee, J. Y. 2004. Plasmodesmata as a supracellular control network in plants. Nat. Rev. Mol. Cell. Biol. 5:712-726.

Mallory, A. C., Reinhart, B. J., Bartel, D., Vance, V. B., and Bowman, L. H. 2002. A viral suppressor of RNA silencing differentially regulates the accumulation of short interfering RNAs and micro-RNAs in tobacco. Proc. Natl. Acad. Sci. U.S.A. 99:15228-15233.

Mayo, M., Ryabov, E., Fraser, G., and Taliansky, M. 2000. Mechanical transmission of Potato leafroll virus. J. Gen. Virol. 81:2791-2795.

Mise, K., and Ahlquist, P. 1995. Host-specificity restriction by bromovirus cell-to-cell movement protein occurs after initial cell-to-cell spread of infection in nonhost plants. Virology 206:276-286.

Mise, K., Allison, R. F., Janda, M., and Ahlquist, P. 1993. Bromovirus movement protein genes play a crucial role in host specificity. J. Virol. 67:2815-2823.

Mitra, R., Krishnamurthy, K., Blancaflor, E., Payton, M., Nelson, R. S., and Verchot-Lubicz, J. 2003. The Potato virus $X$ TGBp2 protein association with the endoplasmic reticulum plays a role in but is not sufficient for viral cell-to-cell movement. Virology 312:35-48.

Morozov, S., Fedorkin, O. N., Juttner, G., Schiemann, J., Baulcombe, D C., and Atabekov, J. G. 1997. Complementation of a Potato virus X mutant mediated by bombardment of plant tissues with cloned viral movement protein genes. J. Gen. Virol. 78:2077-2083.

Morozov, S. Y., and Solovyev, A. G. 2003. Triple gene block: Modular design of a multifunctional machine for plant virus movement. J. Gen. Virol. 84:1351-1366.

Morozov, S. Y., Solovyev, A. G., Kalinina, N. O., Fedorkin, O. N., Samuilova, O. V., Schiemann, J., and Atabekov, J. G. 1999. Evidence for two nonoverlapping functional domains in the Potato virus $X 25 \mathrm{~K}$ movement protein. Virology 260:55-63.

Noueiry, A. O., Chen, J., and Ahlquist, P. 2000. A mutant allele of essential, general translation initiation factor DED1 selectively inhibits translation of a viral mRNA. Proc. Natl. Acad. Sci. U.S.A. 97:12985-12990.

Noueiry, A. O., Lucas, W. J., and Gilbertson, R. L. 1994. Two proteins of a plant DNA virus coordinate nuclear and plasmodesmal transport. Cell 76:925-932.
Oparka, K. J., Roberts, A. G., Boevink, P., Santa Cruz, S., Roberts, I, Pradel, K. S., Imlau, A., Kotlizky, G., Sauer, N., and Epel, B. 1999. Simple, but not branched, plasmodesmata allow the nonspecific trafficking of proteins in developing tobacco leaves. Cell 97:743-754.

Osman, T. A., Thommes, P., and Buck, K. W. 1993. Localization of a single-stranded RNA-binding domain in the movement protein of red clover necrotic mosaic dianthovirus. J. Gen. Virol. 74:2453-2457.

Palukaitis, P., and Garcia-Arenal, F. 2003. Cucumoviruses. Adv. Virus Res. 62:241-323.

Park, J. W., Faure-Rabasse, S., Robinson, M. A., Desvoyes, B., and Scholthof, H. B. 2004. The multifunctional plant viral suppressor of gene silencing P19 interacts with itself and an RNA binding host protein. Virology 323:49-58.

Qin, S., Ward, B. M., and Lazarowitz, S. G. 1998. The bipartite geminivirus coat protein aids BR1 function in viral movement by affecting the accumulation of viral single-stranded DNA. J. Virol. 72:9247-9256.

Qiu, W., Park, J. W., and Scholthof, H. B. 2002. Tombusvirus P19-mediated suppression of virus-induced gene silencing is controlled by genetic and dosage features that influence pathogenicity. Mol. PlantMicrobe Interact. 15:269-280.

Rodionova, N. P., Karpova, O. V., Kozlovsky, S. V., Zayakina, O. V., Arkhipenko, M. V., and Atabekov, J. G. 2003. Linear remodeling of helical virus by movement protein binding. J. Mol. Biol. 333:565-572.

Rojas, M. R., Noueiry, A. O., Lucas, W. J., and Gilbertson, R. L. 1998. Bean dwarf mosaic geminivirus movement proteins recognize DNA in a form- and size-specific manner. Cell 95:105-113.

Rojas, M. R., Zerbini, F. M., Allison, R. F., Gilbertson, R. L., and Lucas, W. J. 1997. Capsid protein and helper component-proteinase function as potyvirus cell-to-cell movement proteins. Virology 237:283-295.

Rollenhagen, C., Hodge, C. A., and Cole, C. N. 2004. The nuclear pore complex and the DEAD box protein Rat8p/Dbp5p have nonessential features which appear to facilitate mRNA export following heat shock. Mol. Cell. Biol. 24:4869-4879.

Roth, B. M., Pruss, G. J., and Vance, V. B. 2004. Plant viral suppressors of RNA silencing. Virus Res. 102:97-108.

Rouleau, M., Smith, R. J., Bancroft, J. B., and Mackie, G. A. 1994. Purification, properties, and subcellular localization of foxtail mosaic potexvirus 26-kDa protein. Virology 204:254-265.

Rout, M. P., Aitchison, J. D., Suprapto, A., Hjertaas, K., Zhao, Y., and Chait, B. T. 2000. The yeast nuclear pore complex: Composition, architecture, and transport mechanism. J. Cell. Biol. 148:635-651.

Ryabov, E. V., Roberts, I. M., Palukaitis, P., and Taliansky, M. 1999. Hostspecific cell-to-cell and long-distance movements of cucumber mosaic virus are facilitated by the movement protein of Groundnut rosette virus. Virology 260:98-108.

Serazev, T. V., Kalinina, N. O., Nadezhdina, E. S., Shanina, N. A., and Morozov, S. Y. 2003. Potato virus $X$ coat protein interacts with microtubules in vitro. Cell Biol. Int. 27:271-272.

Soellick, T., Uhrig, J. F., Bucher, G. L., Kellmann, J. W., and Schreier, P. H. 2000. The movement protein NSm of tomato spotted wilt tospovirus (TSWV): RNA binding, interaction with the TSWV $\mathrm{N}$ protein, and identification of interacting plant proteins. Proc. Natl. Acad. Sci. U.S.A. 97:2373-2378

Solovyev, A. G., Savenkov, E. I., Grdzelishvili, V. Z., Kalinina, N. O., Morozov, S. Y., Schiemann, J., and Atabekov, J. G. 1999. Movement of hordeivirus hybrids with exchanges in the triple gene block. Virology 253:278-287.

Solovyev, A. G., Zelenina, D. A., Savenkov, E. I., Grdzelishvili, V. Z., Morozov, S. Y., Lesemann, D. E., Maiss, E., Casper, R., and Atabekov, J. G. 1996. Movement of a Barley stripe mosaic virus chimera with a Tobacco mosaic virus movement protein. Virology 217:435-441.

Storms, M. M., Nagata, T., Kormelink, R., Goldbach, R. W., and van Lent, J. W. 2002. Expression of the movement protein of Tomato spotted wilt virus in its insect vector Frankliniella occidentalis. Arch. Virol. 147:825-831

Syller, J. 2002. Umbraviruses - the unique plant viruses that do not encode a capsid protein. Acta Microbiol. Pol. 51:99-113.

Tamada, T., Schmitt, C., Saito, M., Guilley, H., Richards, K., and Jonard, G. 1996. High resolution analysis of the readthrough domain of Beet necrotic yellow vein virus readthrough protein: A KTER motif is important for efficient transmission of the virus by Polymyxa betae. J. Gen. Virol. 77:1359-1367.

Tamai, A., Kubota, K., Nagano, H., Yoshii, M., Ishikawa, M., Mise, K., and Meshi, T. 2003. Cucumovirus- and bromovirus-encoded movement functions potentiate cell-to-cell movement of tobamo- and potexviruses. Virology 315:56-67.

Tamai, A., and Meshi, T. 2001. Cell-to-cell movement of Potato virus X: The role of p12 and p8 encoded by the second and third open reading frames of the triple gene block. Mol. Plant-Microbe Interact. 14:1158-1167. 
Verchot, J., Angell, S. M., and Baulcombe, D. C. 1998. In vivo translation of the triple gene block of Potato virus $X$ requires two subgenomic mRNAs. J. Virol. 72:8316-8320.

Voinnet, O., Lederer, C., and Baulcombe, D. C. 2000. A viral movement protein prevents spread of the gene silencing signal in Nicotiana benthamiana. Cell 10:157-167.

Voinnet, O., Pinto, Y. M., and Baulcombe, D. C. 1999. Suppression of gene silencing: A general strategy used by diverse DNA and RNA viruses of plants. Proc. Natl. Acad. Sci. U.S.A. 96:14147-14152.

Wolf, S., Deom, C. M., Beachy, R., and Lucas, W. J. 1991. Plasmodesmatal function is probed using transgenic tobacco plants that express a virus movement protein. Plant Cell 3:593-604.

Yang, Y., Ding, B., Baulcombe, D. C., and Verchot, J. 2000. Cell-to-cell movement of the $25 \mathrm{~K}$ protein of Potato virus $X$ is regulated by three other viral proteins. Mol. Plant-Microbe Interact. 13:599-605.

Yelina, N. E., Savenkov, E. I., Solovyev, A. G., Morozov, S. Y., and Valkonen, J. P. 2002. Long-distance movement, virulence, and RNA silencing suppression controlled by a single protein in hordei- and potyviruses: Complementary functions between virus families. J. Virol. 76:12981-12991.

Zambryski, P. 2004. Cell-to-cell transport of proteins and fluorescent tracers via plasmodesmata during plant development. J. Cell. Biol. 164:165-168. 